\title{
Assessment and Management of Factors of the Regional Investment Potential
}

\author{
Irina Mikhailovna Golaydo ${ }^{1} \&$ Yuliya Pavlovna Soboleva ${ }^{1}$ \\ ${ }^{1}$ The Federal State Budgetary Educational Establishment of Higher Professional Education "The Orel State \\ Institute of Economics and Trade", (Orel SIET), Russia \\ Correspondence: Yuliya Pavlovna Soboleva, The Federal State Budgetary Educational Establishment of Higher \\ Professional Education "The Orel State Institute of Economics and Trade", (Orel SIET), Oktyabrskayast., 12, \\ Orel, Russia. Tel: 79-19-264-9376. E-mail: soboleva-yp@mail.ru
}

Received: November 1, 2014 Accepted: December 23, 2014 Online Published: March 16, 2015

doi:10.5539/ass.v11n 7 p240

URL: http://dx.doi.org/10.5539/ass.v11n7p240

\begin{abstract}
The article is devoted to the questions of the territory investment potential valuation. It is the valuation system of distinctions in territories characteristics and their comparisons that are especially actual and necessary for investors as territories differ in labour, financial, natural and other resources, and various conditions created for investors by governing bodies. The article suggests the solution of this problem by calculating a total evaluative indicator, that is, territory investment potential. The authors of article present the analysis results of a number of various valuation techniques of investment potential, and mark the main advantages and disadvantages of existing approaches and valuation techniques. In the article the author's technique of valuation of territory investment potential is suggested. It is based on the analysis of factors influencing investment potential. The technique takes into account inflationary, political and social risks because stable political, economic and social situation is important for an investor. On the basis of the technique developed by the authors investment potential of a separate territory was calculated and forecasted.
\end{abstract}

Keywords: regional investment potential, budgetary and regional efficiency of investments, federal target investment programs, interregional investment potential, funds for investment potential increase

\section{Introduction}

Investments are a guaranty of economic development and growth of the national income of the regions. Nowadays the states and their regions are tasked with required quantity of investment borrowings (Breinlich, Ottaviano, \& Temple, 2014). Regions differ from each other with their labor, financial, natural and other resources, and also have various conditions created for investors by governing bodies (Sabirova, Fazlyeva, \& Feifer-Shishkina, 2014). It is the system of an assessment of distinctions in characteristics of the regions and their comparison that is especially actual and necessary for investors. Having calculated a cumulative estimated indicator which can be considered the regional investment potential we can solve this problem.

There is a set of various techniques of an assessment of the investment potential. However the carried-out analysis of their features allowed us to note that the terminological divergences in various works, distort semantic loading of the category "investment potential" and limit the possibilities of its application in the analysis of economic systems.

\section{Methods}

\subsection{Characterization Methods for Evaluating Investment Potentia}

So, according to A. A. Miroyedov, the regional investment potential is an ability to obtain the greatest possible volume of an investment component of GRP which is realized by means of use of investment factors of economic growth (Miroyedov \& Sharamigina, 2013). V. A. Sivelkin and G. S. Poltavchenko define it as a set of the investment resources which make up the part of the saved-up capital which is presented in the investment market in the form of the potential investment demand which is capable and have an opportunity to turn into the real investment demand providing the satisfaction of material, financial and intellectual requirements of reproduction of the capital (Sivelkin \& Poltavchenko, 2002). 
L. N. Bulgakova notes in her studies that investment potential is not a simple set, it is an ordered system of the investment resources that allows to achieve synergetic effect of their use (Bulgakova, 2012).

In treatment of an investment appeal rating of Russian regions of "Expert" group investment potential "has to consider macroeconomic characteristics, a territory saturation with production factors, the consumer demand of the population and it consists of seven separate potentials (Expert RA Rating Agency, 2014):

1. Resource and raw materials (average self-sufficiency with balance stocks of main types of natural resources);

2. Labor (manpower and educational level);

3. Production potential (cumulative result of economic activity of the population in the region);

4. Institutional potential (extent of development of leading institutes in a market economy);

5. Infrastructure (economical geographical position of the region and its infrastructure security);

6. Financial potential (volume of tax base and profitability of the enterprises in the region);

7. Consumer potential (cumulative purchasing power of the population in the region)".

As a result of the diversity of views on the concept of "investment potential" can be represented in terms of a number of approaches (Figure 1).

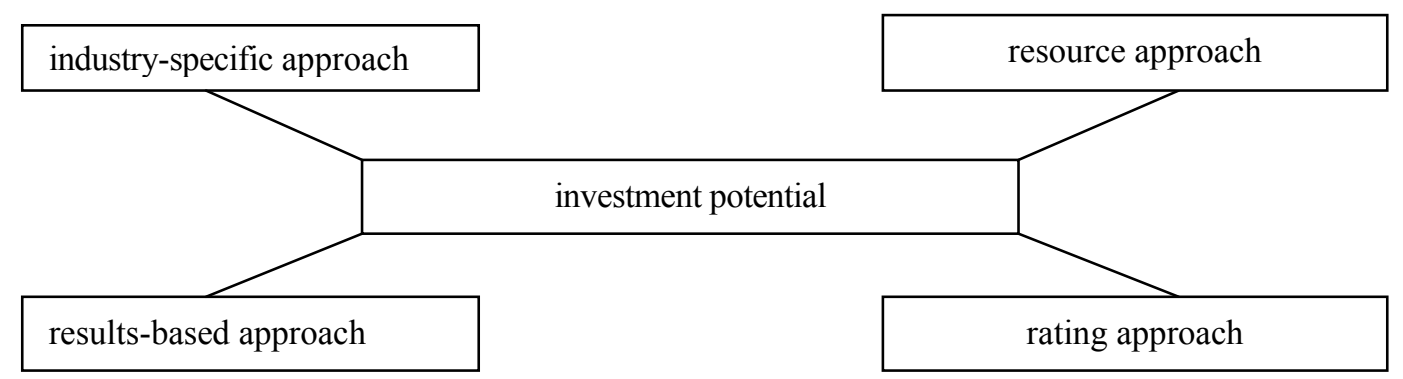

Figure 1. The main approaches to the assessment of investment potential

The comparative characteristic of the techniques existing within listed approaches is represented in Table 1.

Table 1. The comparative characteristic of approaches to an assessment of investment potential

\begin{tabular}{ccc}
\hline $\begin{array}{c}\text { Authors of } \\
\text { techniques }\end{array}$ & Advantages & Disadvantages \\
1 & 2 & 3 \\
\hline
\end{tabular}

results-based approach

Y. A. Doroshenko defines the income which can be received doesn't open the essence of the category during a certain time of investment "investment potential" as identifies it with a resources functioning cash flow from investments

industry-specific approach

T. S. Khachaturov, the important attention is paid to the essence of the category "investment V.P. Krasovsky development of the fund-creating branches potential" is reduced to the category "production potential"

resource approach

M. I. Akimov, S. allows to estimate a set of available sources A. Popova of formation of investment resources

rating approach

L. N. Bulgakova, allows to estimate investment systems "Expert RA" quantitatively and to appropriate the rating agency corresponding rating to regions and branches estimates level of the financial resources used for functioning of economic system and doesn't open essence of investment potential

lack of coherence in definition of the category "investment potential"; illegibility of methodical bases of an assessment of some parameters of investment potential 


\subsubsection{The Concept of Income}

There are scientific works containing both approaches to explanation of essence of the category "investment potential" and basis of its assessment. According to Y. A. Doroshenko, investment potential is a total income which can be received during a certain period of functioning of investment resources.

The parameters of investment resources included in calculation are elements of the fixed and working capital. Thereby investment potential according to Y. A. Doroshenko's concept is the current discounted cost of the income which is forming as a result of using business assets that defines a level of development of the production sphere and serves as the characteristic of one of the parties of investment potential (Doroshenko \& Baidina, 2008).

For this reason the use of the offered technique for researching the investment process is limited to assumptions of the framework of categories and concepts and it is possible only for researching the investment potential of economic system.

\subsubsection{Industry Concept}

The special attention should be paid to explanation of category "investment potential" on the basis of the industry-specific approach.This approach is based on an analogy between the investment potential and a complex of fund-creating branches. According to T. S. Khachaturov (Khachaturov, 1973), V. P. Krasovsky besides the construction industry carrying out construction works and installation of equipment, this complex includes machine production and the equipment for new, expanded and reconstructed enterprises, production of constructional materials and the construction machines used in capital construction.

Thus, there is a compression of the essence of "investment potential" and its reduction to the category "production potential" which level is defined by development of the largest industrial and transport enterprises in the region, or to the category "construction potential" characterized by parameters of a capital intensity of construction works, a gain of the national income per rouble of invested funds, capacities of the construction organizations (Åslund, 2012).

\subsubsection{The Resource Approach}

Resource approach is well-known nowadays. Within this approach the category "investment potential" is reduced to the potential of investment resources, i.e. to sources of their formation, such as profit, depreciation charges, contributions to various non-budget funds, assets of public and commercial financial institutions and population savings. Or category "investment potential" is reduced to a set of opportunities and available investment resources which are influenced by the whole system of factors and conditions and are realized through investment streams (Lavrov \& Sdasyuk, 1984).

Within resource approach the investment process research is shifted toward a position of the investor as there is an assessment of his potential opportunities of capital investments, or toward the estimation of the level of financial resources used for functioning of economic system. In both cases the essence of investment potential is not revealed, and this limits a scope of resource approach for the solution of problems of an investment perspective.

\subsection{Factors of Investment Potential}

One more group of scientific papers includes works in which investment potential is defined as "the sum of depreciation charges and net profit remaining after tax payment ", i.e. productive approach is used as a methodological basis. In this case investment potential is defined as an output of resources used. This approach doesn't clarify the essence of category "investment potential" and narrows the area of its application, because within such an approach the investment potential and a cash flow from investments are identified.

The works of A. Folomyev and V. Revazo constitute a separate group which ultimate goal is to arrange economic systems according to investment potential (Folomyev \& Revazo, 1999). Such target setting defines also the nature of research supposing the detailed structuring of investment potential and further association of components in an integrated indicator. For example, investment potential includes seven separate potentials:

-Resource and raw materials (self-sufficiency with the main types of natural resources);

-Production potential (cumulative result of economic activity of the population);

-Consumer potential (cumulative purchasing power of the population);

-Infrastructure (economical geographical position of the region and its infrastructure security);

-Intellectual potential (educational level of the population); 
-Institutional potential (the extent of development of leading institutes of market economy);

-Innovative potential (level of introduction of scientific and technical achievements) (Safiullina, Fatkhiev, \& Ulesov, 2014).

An undeniable advantage of these works is that they include a lot of quantitative estimates of investment potential of the economic systems which allows to analyze regions and industries and to assign them the corresponding rating.

The disadvantages of this approach are: the lack of coherence in defining the considered category which is treated either as the sum of objective prerequisites of investment or as a set of indicators of regional development among which are the main macroeconomic indicators, a territory saturation production factors (natural resources, labor, fixed assets, infrastructure, etc.), a consumer demand of the population, etc.; illegibility of methodical bases of an assessment of such parameters of investment potential as institutional and innovative potential.

\section{Results}

\subsection{The Consolidation of Industry and Rating Methods}

We consider the technique offered by L. N. Bulgakova which unites industry-specific and rating approaches to be especially interesting.

For an assessment of investment potential of the region in this case we should use the indicator which estimates potential of the production branch including an assessment of such factors as a number of employees, the total output, security with equity funds and credit resources, degree of production intensification and its efficiency, for the branch production in the region and in the country defined by its elasticity.

Taking into account the considered approaches the investment potential of the territory can be characterized as the ability of the territory "to absorb the capital". Thus it is possible to speak about some limits of investments which the territory is capable "to absorb" depending on its objective characteristics (Shmelev, 2011).

Taking into account the considered approaches to determination of investment potential in this research, in our opinion, it is necessary to understand the investment potential of the region as a set of factors influencing macroeconomic characteristics of the region and the development of investment processes in it.

The analysis of investments from a position of investment potential allows us to state that many investors collective and private - have great opportunities and desires for investments (Babkin, Kudryavtseva, \& Utkina, 2013). However, operating only with an indicator of investment potential, it is impossible to define where these investments will be made.

\subsection{Investment Risk}

Therefore, in our opinion, the use of characteristics of investment risk is also required (Săvoiu \& Țaicu, 2014). The definitions of investment risk are based on various approaches of its definition and classifications. So, L.S. Valinurova and O. B. Kazakova in their works emphasized three groups of approaches to treatment of the category "investment risk" (Table 2) (Valinurova \& Kazakova, 2013).

Table 2. The main approaches to definition of investment risk

1

approach

2

approach

3

approach

The investment risk is the risk which is connected with loss of profit from the project entirely due to inefficient investment of funds. This approach narrows the area of occurrence of investment risk, isolates the investor from other types of risks and increases the possibility of underestimation of expected losses.

The investment risk is any risk arising during the investment activity and is characterized by opportunity or probability of full or partial loss of profit from investments. This approach allows to predict the maximum losses in case of arising the events generating risk and therefore it is applicable in any areas and at any levels of investment.

The investment risk as separate category is absent in the nature of economic events, and the losses arising during investment activity, are caused by interaction of other types of risk. This approach distorts essence of the concept "risk", brings uncertainty to the approaches defining other types of risk, for example, financial, and reduces reliability of an assessment of the expected profit of the investor. 
Depending on the reasons of occurrence and opportunities of elimination (compensation) there are two types or two components of the general investment risk:

-Specific, or commercial, investment risk (some authors it is designated as internal risk);

-Nonspecific, or noncommercial, investment risk (external risk).

Specific investment risk is a kind of entrepreneurial risk connected with investment activity and caused by specific features of commercial activity of any investment project or a separate enterprise (corporation).

Commercial investment risks occur only during business activity and have no macroeconomic, regional and industry-specific forms.

Nonspecific investment risk is caused by external circumstances of macroeconomic, regional character in relation to investors. These are the risks that compose a part of the regional investment appeal.

Macroeconomic and regional investment risks can be only noncommercial or nonspecific. They influence probable results of implementation of all investment projects to the same extent in the country, the region or the industry. Therefore, quantitative values of such risks have to be considered in case of state regulation of investment processes and during calculating the indicators of investment projects efficiency.

The other group of authors distinguish the following types of risks for an assessment of investment climate (Podshivalenko \& Kiselyova, 2005):

-Political risk (it depends on stability of the regional authority and on political polarization of the population);

-Economic risk (it is connected with dynamics of economic processes in the region);

-Social risk (it emphasizes the level of social strain);

-Criminal risk (it defines a crime rate taking into account the gravity of offence);

-Ecological risk (it is an integrated level of environmental pollution);

-Financial risk (it reflects the intensity of the regional budget and cumulative financial results of activity of the enterprises in the region);

-Legislative risk (it characterizes a set of legal rules regulating the economic relations in the territory: local taxes, benefits, restrictions).

It should be noted that investment risk is a more qualitative than quantitative characteristic and is expected to change rather quickly, because unlike investment potential it depends on qualitative components (political, social, economic, and other characteristics of regional investment conditions) which are very dynamic as a rule (Platon \& Constantinescu, 2014).

\subsection{Formula Investment Climate}

Taking into account characteristics of existing approaches to the concept "investment risk" we suggest understanding investment risk as the probability of losses or shortage of the planned results during investment activity.

The condition for investment potential realization makes up the category of investment climate with a certain degree of investment risk.

This is the generalized formula of investment climate:

Investment climate $=$ Investment potential - Investment risks

Therefore, investment potential is the basic characteristic of investment climate in the region. Nowadays there is no standard technique of determination of investment potential of the region which completely considers all main characteristics of the regional investment processes (Kihlgren, 2003).

The most complete characteristic of investment potential, in our opinion, is represented in works of rating character (L. N. Bulgakova's technique and the technique of "Expert RA" rating agency). They offer the unified approaches to an assessment of investment potential and the tools for a comparative assessment on the accepted circle of parametrical characteristics of social and economic development. However, these techniques don't allow to estimate the investment potential of a particular region as well as to consider its specific features.

Besides, the investment potential of the region in the above-mentioned works is considered as a rule from a position of the abstract strategic investor who is seeking for accelerated, maximum, free profit receiving. But the capital as well as investments can be rather diverse, and investors can pursue different aims. Interests and 
priorities of investors can differ depending on the character and industry-specific orientation of potential investments in economy.

As a rule the recipient of investments and the investor pursue different aims. The former seeks to solve a complex of social and economic tasks with a minimum of raised funds, the latter seeks to receive maximum profit and to build a stable business in the market for a long period of time. Therefore, investment potential has to be in accord with a balance of interests (Castells \& Solé-Ollé, 2005). We also think that while estimating an assessment of investment potential it is necessary to consider characteristics of some investment risks, such as inflationary and social as they make direct impact on territorial investment processes.

Thus, we need a technique that will allow us to estimate the investment potential of a particular region and which can also change depending on features of a particular region and on investors' priorities.

\subsection{The Factors and Indicators that Determine the Investment Potential of the Area}

For an assessment of investment potential of the region we used the analysis of factors that make up the investment potential of the region and the indicators characterizing their impact (Table 3).

Table 3. Factors and indicators determining investment potential of the territory

\begin{tabular}{|c|c|}
\hline Indicators & An assessment of an indicator \\
\hline & Production-based factor \\
\hline Output increase & $\begin{array}{c}\text { The ratio of output in the current period to the output in the previous } \\
\text { period }\end{array}$ \\
\hline utput per capita & The ratio of output to population size of the region \\
\hline $\begin{array}{l}\text { Percentage of output in the region in } \\
\text { output in the country }\end{array}$ & The ratio of output in the region to total production in the country \\
\hline \multirow[t]{2}{*}{ Degree of monopoly } & $\begin{array}{c}\text { The ratio of number of the enterprise-monopolists to total number of } \\
\text { the enterprises }\end{array}$ \\
\hline & Financial factor \\
\hline Taxation level & $\begin{array}{c}\text { The ratio of taxation volume to the volume of a gross regional } \\
\text { product }\end{array}$ \\
\hline Dynamics of taxation level & $\begin{array}{l}\text { The ratio of taxation level in the current year to taxation level in the } \\
\text { previous period }\end{array}$ \\
\hline $\begin{array}{c}\text { Degree of financing in the regional } \\
\text { budget }\end{array}$ & $\begin{array}{c}\text { The ratio of expenses on financing the economy to the regional } \\
\text { budget }\end{array}$ \\
\hline & Macroeconomic factor \\
\hline $\begin{array}{c}\text { The increase of gross regional product } \\
\text { volume }\end{array}$ & $\begin{array}{l}\text { The ratio of gross regional product volume in the current year to } \\
\text { gross regional product volume in previous year }\end{array}$ \\
\hline $\begin{array}{c}\text { The expected growth of gross regional } \\
\text { product }\end{array}$ & It is defined as an expected growth value of gross regional product \\
\hline Dynamics of inflation & The ratio of inflation in the current year to inflation in previous year \\
\hline \multirow[t]{2}{*}{ Current inflation } & According to statistical data \\
\hline & Export-based factor \\
\hline Export growth & $\begin{array}{l}\text { The ratio of export volume in the current year to export volume in } \\
\text { previous year }\end{array}$ \\
\hline \multirow[t]{2}{*}{ Export volume per capita } & The ratio of export volume to population size in the region \\
\hline & Resource-based factor \\
\hline Volume of natural resources per unit area & The ratio of volume of natural resources to the regional area \\
\hline Volume of natural resources per capita & $\begin{array}{c}\text { The ratio of volume of natural resources to population size of the } \\
\text { region }\end{array}$ \\
\hline
\end{tabular}




Indicators
Investments increase
Percentage of investments into fixed
capital
The benefits provided to investors
Rate of introducing the achievements of
scientific-and-technological advance

State ownership

Increase of a consumer demand

State of environment

Labour supply and labour cost

Average wages

Unemployment rate

Qualification and quality of labor fource

Population standard of living

Assessment of social stability

Importance of the region

Level of development of objects of infrastructure

Availability of objects of infrastructure
An assessment of an indicator

Investment-based factor

The ratio of the investment volume in the current year to the volume of investment in previous year

The ratio of the investment volume into fixed capital to the total amount of investments of the region

Qualitative evaluation

Innovation-based factor

Time line necessary introducing the achievements of scientific-and-technological advance in production from the moment of their registration (according to statistical data)

Political factor

The share of state ownership in the region

Consumer-based factor

The ratio of consumption volume in the current year to consumption volume in previous year

Ecological factor

Qualitative evaluation

Labour-based factor

The average cost of one working hour in the region (according to statistical data)

According to statistical data

According to statistical data

Intellectual factor

Percentage of population with the higher and secondary vocational education (according to statistical data)

Social factor

Percentage of the population which is living below poverty line (according to statistical data)

Qualitative evaluation

Percentage of labour fource occupied in the region in the total labour fource occupied in the country

Infrastructure-based factor

The ratio of number of objects of infrastructure to the territory area

The ratio of cost of single use of objects of infrastructure to the average wages in the region

\subsection{Evaluation of the Factors of Investment Attractiveness}

The structure of factors and their indicators offered in our paper meets the purpose of making a technique of an assessment of regional investment potential because it considers the main characteristics of investment process in the region. The structure of indicators can be changed due to specific nature of conditions and the directions of investment, the investors' priorities, features of economic development on each stage, and features of each particular region (Batabyal, 2012). To compare the indicators characterizing investment potential we offer the ten-mark scale to evaluate each indicator (Table 4). 
Table 4. The scale of an assessment of indicators of the regional investment potential

\begin{tabular}{|c|c|c|}
\hline Indicator & Indicator evaluation & $\begin{array}{l}\text { Weight } \\
\text { number }\end{array}$ \\
\hline 1 & 2 & 3 \\
\hline Industrial output increase & $\begin{array}{l}1 \text { - over } 10 \text { per cent increase } \\
10 \text { - over } 10 \text { per cent decrease }\end{array}$ & 0,302 \\
\hline Output per capita & $\begin{array}{l}1-\$ 10000 \\
10-\$ 100\end{array}$ & 0,202 \\
\hline Percentage of regional output in total output in the country & $\begin{array}{l}1-\mathrm{d} / \mathrm{d} 10 \text { per cent } \\
10-\text { below } 1 \text { per cent }\end{array}$ & 0,282 \\
\hline Degree of monopoly & $\begin{array}{l}1 \text { - below } 5 \text { per cent } \\
10 \text { - over } 30 \text { per cent }\end{array}$ & 0,181 \\
\hline Taxation level & $\begin{array}{l}1-\text { low } \\
10-\text { very high }\end{array}$ & 0,383 \\
\hline Dynamics of taxes level & $\begin{array}{l}1-\text { taxes are expected to be reduced } \\
10 \text { - taxes are expected to be increased }\end{array}$ & 0,383 \\
\hline Percentage of financing the region in the regional budget & $\begin{array}{l}1-\text { from } 90 \text { to } 100 \text { per cent } \\
10 \text { - below } 10 \text { per cent }\end{array}$ & 0,060 \\
\hline The increase of gross regional product volume & $\begin{array}{l}1 \text { - over } 10 \text { per cent increase } \\
10 \text { - over } 10 \text { per cent decrease }\end{array}$ & 0,403 \\
\hline The expected growth of gross regional product & $\begin{array}{l}1 \text { - over } 10 \text { per cent increase } \\
10 \text { - over } 10 \text { per cent decrease }\end{array}$ & 0,403 \\
\hline Dynamics of inflation & $\begin{array}{l}1 \text { - essential decrease } \\
10 \text { - dramatic upturn }\end{array}$ & 0,282 \\
\hline Current inflation & $\begin{array}{l}1-\text { no more than } 3 \text { per cent } \\
10-100 \text { per cent and more }\end{array}$ & 0,323 \\
\hline Export growth & $\begin{array}{l}1 \text { - over } 10 \text { per cent increase } \\
10 \text { - over } 10 \text { per cent decrease }\end{array}$ & 0,060 \\
\hline Export volume per capita & $\begin{array}{l}1-\$ 10000 \\
10-\$ 100\end{array}$ & 0,060 \\
\hline Volume of natural resources per unit area & $\begin{array}{l}1-\$ 10000 \\
10-\$ 100\end{array}$ & 0,040 \\
\hline Volume of natural resources per capita & $\begin{array}{l}1-\$ 10000 \\
10-\$ 100\end{array}$ & 0,020 \\
\hline Investments increase & $\begin{array}{l}1 \text { - over } 10 \text { per cent increase } \\
10 \text { - over } 10 \text { per cent decrease }\end{array}$ & 0,605 \\
\hline Percentage of investments into fixed capital & $\begin{array}{l}1-\text { from } 90 \text { to } 100 \text { per cent } \\
10 \text { - below } 10 \text { per cent }\end{array}$ & 0,585 \\
\hline The benefits provided to investors & $\begin{array}{l}1 \text { - provided and stimulate the investments } \\
10 \text { - not provided }\end{array}$ & 0,625 \\
\hline $\begin{array}{l}\text { Rate of introducing the achievements of } \\
\text { scientific-and-technological advance }\end{array}$ & $\begin{array}{l}1 \text { - introduced within a year from the moment of their registration } \\
10 \text { - introduced within more than } 7 \text { years }\end{array}$ & 0,343 \\
\hline State ownership in the region & $\begin{array}{l}1-\text { below } 10 \text { per cent } \\
10 \text { - from } 90 \text { to } 100 \text { per cent }\end{array}$ & 0,181 \\
\hline Increase of a consumer demand & $\begin{array}{l}1 \text { - over } 10 \text { per cent increase } \\
10 \text { - over } 10 \text { per cent decrease }\end{array}$ & 0,444 \\
\hline State of environment & $\begin{array}{l}1-\text { satisfactory } \\
10-\text { serious problems }\end{array}$ & 0,141 \\
\hline Labour supply and labor cost & $\begin{array}{l}1 \text { - surplus of low-paid manpower } \\
10 \text { - shortage of labour supply }\end{array}$ & 0,524 \\
\hline Qualification and quality of labor fource & $\begin{array}{l}1-\text { high } \\
10-\text { lack of skilled labor fource }\end{array}$ & 0,544 \\
\hline Average wages & $\begin{array}{l}1 \text { - higher than national average } \\
10 \text { - lower than national average }\end{array}$ & 0,464 \\
\hline Unemployment rate & $\begin{array}{l}1 \text { - full employment } \\
10 \text { - more than } 25 \text { per cent of work fource }\end{array}$ & 0,444 \\
\hline Population standard of living & $\begin{array}{l}1-\text { more than } 50 \% \text { of the population } \\
\text { live above an average } \\
10 \text { - the most part of the population lives below the poverty line }\end{array}$ & 0,544 \\
\hline Assessment of social stability & $\begin{array}{l}1-\text { steadiness } \\
10-\text { social strain }\end{array}$ & 0,222 \\
\hline Importance of the region & $\begin{array}{l}1-\text { from } 10 \text { per cent } \\
10-\text { below } 1 \text { per cent }\end{array}$ & 0,141 \\
\hline Level of development of objects of infrastructure & $\begin{array}{l}1-\text { high } \\
10-\text { low }\end{array}$ & 0,363 \\
\hline Availability of objects of infrastructure & $\begin{array}{l}1-\text { available to everyone } \\
10 \text { - provided selectively }\end{array}$ & 0,343 \\
\hline
\end{tabular}




\subsection{The Importance of Factors}

Values of weight numbers for each indicator are also presented in table 4. Weight numbers demonstrate the relative importance of an indicator in comparison with other indicators. They were calculated by means of a curve of emphases. Arrangement of priorities on the curve was carried out by heads of financial departments of the enterprises and the individual entrepreneurs who are considered to be potential investors. The average result was calculated by means of enquiry.

Values of weight numbers can also vary depending on investors' priorities and a particular region specialties. Theoretically while estimating regional investment potential the investor has to attach his priorities to indicators offered in a curve of emphases. Thus, the technique is adapted and extremely close to interests of the investor.

Having estimated the above-mentioned indicators we determine the value of regional investment potential by the formula:

$$
I P=\frac{\sum_{i=1}^{n} K_{i} \times g_{i}}{\sum_{i=1}^{n} g_{i}},
$$

where $I P$ means regional investment potential;

$n$ is a number of indicators;

$K_{i}$ is the indicator's characteristics

$g_{i}$ - weight number.

Depending on value of an indicator's received, we offered the following classification of regions (Table 5).

Table 5. Classification of regions by an indicator of investment potential

\begin{tabular}{cc}
\hline Value of an indicator of investment potential & Characteristics of the region potential \\
\hline $1-2$ & maximum potential \\
$2-4$ & high potential \\
$4-6$ & average potential \\
$6-8$ & lower potential \\
$8-10$ & insignificant potential \\
\hline
\end{tabular}

\section{Discussion}

The assessment of investment potential of the Oryol region was made on the basis of analysis of the following factors: financial, production-based, export-based, macroeconomic, resource-based, investment-based, innovation-based, political, consumer-based, ecological, intellectual, social and infrastructure-based (Soboleva \& Golaydo, 2014).

As a whole, the economy of the region is represented by all types of economic activities with agriculture, manufacturing sector, construction, transport and communication, trade as the most important.

The region has an adequate productive and economic potential with agro-industrial orientation for dealing with intraregional problems, and also for standard interaction at interregional level according to the customary division of labor. It is noted that the Oryol region has a number of significant advantages having a number of conductive conditions for restructuring. They primarily include favorable climatic conditions for sustain agriculture and self-sufficiency with basic foodstuffs, low level of economic militarization, rather developed transport network, a favorable geographical position of the territory, rather stable social situation (Golaydo, 2008).

At the same time the Oryol region has many specific features commonly found in Russian economy as a whole. First of all they include an extensive depreciation and an obsolescence of fixed assets, a high material capacity and power consumption of production alongside with an insufficient technical level and a poor quality of production, low production efficiency in agriculture alongside with high technological losses and low refinery yield, a comparatively small share of exports, a large share of manual labour. 
On the basis of the data obtained as a result of our research we managed to calculate the total investment potential of the Oryol region. This technique was also used for forecasting of the regional investment potential (Golaydo, 2009).

It is also necessary to consider the degree of impact on each of the indicators characterizing investment potential.

Depending on response to actions from the subject of management all indicators characterizing the regional investment potential can be classified into the indicators which are practically unresponsive to influence; the indicators which are slightly responsive to influence; the indicators which are moderately responsive to influence; the indicators which are quickly but not always fully changing as a result of influence; the indicators which are quickly changing as a result of influence (Table 6) (Breinlich, Ottaviano, \& Temple, 2014).

Table 6. Classification of the indicators characterizing investment potential depending on influence perception by the subject of management

\begin{tabular}{|c|c|}
\hline A set of indicators & Indicators \\
\hline 1 & 2 \\
\hline $\begin{array}{l}\text { 1. The indicators which are } \\
\text { practically unresponsive to } \\
\text { influence }\end{array}$ & $\begin{array}{l}\text { volume of natural resources per capita, volume of natural resources per unit } \\
\text { area }\end{array}$ \\
\hline $\begin{array}{l}\text { 2. The indicators which are } \\
\text { slightly responsive to influence }\end{array}$ & population standard of living, unemployment rate, sta \\
\hline $\begin{array}{l}\text { 3. The indicators which are } \\
\text { moderately responsive to } \\
\text { influence }\end{array}$ & GRP growth, current inflation, dynamics of inflation, export \\
\hline $\begin{array}{l}\text { 4. The indicators which are } \\
\text { quickly but not always fully } \\
\text { changing as a result of influence }\end{array}$ & $\begin{array}{l}\text { investment increase, production increase, taxation level, taxation dynamics, } \\
\text { level of infrastructure development and its availability }\end{array}$ \\
\hline $\begin{array}{l}\text { 5. The indicators which are } \\
\text { quickly changing as a result of } \\
\text { influence }\end{array}$ & $\begin{array}{l}\text { labour supply and labour cost, quality of labor fource, degree of monopoly } \\
\text { in the region, rate of introducing the achievements of } \\
\text { scientific-and-technological advance and benefits provided to investors }\end{array}$ \\
\hline
\end{tabular}

Finally we arrived at the conclusion that it is possible to influence the regional investment potential by means of impact on production increase, taxation level, taxation dynamics, a level of infrastructure development and its availability, investments increase, labour supply and labour cost, quality of labor fource, degree of monopoly in the region, rate of introducing the achievements of scientific-and-technological advance and benefits provided to investors (Rolik, 2013).

Dynamics of investment potential of the Oryol region in 2008-2014 is represented in Table 7 (Soboleva \& Golaydo, 2014).

The data analysis of Table 7 allows us to determine that dynamics of investment potential for the considered period is positive.Every year its value grows closer to 1 which is the highest assessment in our technique; it corresponds to the characteristic "the maximum potential".

Table 7. Dynamics of investment potential of the Oryol region in 2008-2014

\begin{tabular}{cccccccc}
\hline Indicator & 2008 & 2009 & 2010 & 2011 & 2012 & $\begin{array}{c}2014 \\
\text { (forecast) }\end{array}$ & $\begin{array}{c}\text { Deviation } \\
(+;-)\end{array}$ \\
\hline 1 & 2 & 3 & 4 & 5 & 6 & 7 & 8 \\
Investment potential, unit & 4,139 & 4,157 & 3,271 & 3,428 & 3,208 & 2,884 & $-1,255$ \\
$\begin{array}{c}\text { Rate of increase (reduction) of } \\
\text { investment potential, per cent }\end{array}$ & - & $+0,43$ & $-21,31$ & $+4,80$ & $-6,42$ & $-10,10$ & $-9,67$ \\
\hline
\end{tabular}

\section{Conclusions}

Thus, it is possible to draw the conclusion that the developed technique of an assessment of regional investment potential respects interests of potential investors as well as regional characteristics and allows to estimate the potential of each region without definition of its location in general. 
It should be noted that the advantage of the developed technique of an assessment of regional investment potential is that the information required for an assessment is available, and this fact considerably facilitates the analysis of investment potential. This technique can be also adapted and changed depending on features of the region and of investors' requirements; it can also be used for the current state analysis of the region separately without comparative analysis of regions, as well as for comparison of regions with each other.

We used this technique for an assessment of investment potential of the Oryol region. The analysis of investment potential of the Oryol region in 2008-2014 showed that among the above-mentioned the following factors were estimated as low: level of infrastructure development and its availability, labour supply and labour cost, quality of labor fource, rate of introducing the achievements of scientific-and-technological advance and benefits provided to investors. These are the directions that require the investment potential increase, and these are the factors that need special attention.

We think this is especially important in a situation when an investor chooses the directions for future investments. However, he has no sufficient information for comparative analysis of the investment potential of all regions while the rating assessment made by agencies doesn't consider his individual preferences and priorities. The offered technique of an assessment of investment potential allows to solve these problems and to estimate the regional investment potential on the basis of available statistical data on dynamics of the main socio-economic indicators.

\section{Acknowledgments}

The article was prepared within the framework of the execution state of the job of the Ministry of education and science of the Russian Federation (task 2014/512).

\section{References}

Åslund, A. (2012). How entrepreneurship could be promoted after the collapse of a socialist economic system. Journal of Asian Economics, 23(2), 157-167. http://dx.doi.org/10.1016/j.asieco.2011.09.003

Babkin, A., Kudryavtseva, T., \& Utkina S. (2013). Formation of Industrial Clusters Using Method of Virtual Enterprises. Procedia Economics and Finance, 5, 68-72. http://dx.doi.org/10.1016/S2212-5671(13)00011-7

Batabyal, A. A. (2012). Project financing, entrepreneurial activity, and investment in the presence of asymmetric information. The North American Journal of Economics and Finance, 23(1), 115-122. http://dx.doi.org/10. 1016/j.najef.2011.11.006.

Breinlich, H., Ottaviano, G., \& Temple, J. (2014). Regional Growth and Regional Decline. Handbook of Economic Growth (pp. 683-779). Elsevier: Handbook of Economic Growth. http://dx.doi.org/10.1016/ B978-0-444-53540-5.00004-5

Bulgakova, L. N. (2012). Methodological aspects of estimation of socio-economic potential of region. Retrieved from http://www.uecs.ru/uecs-37-372012/item/1004-2012-02-01-05-52-52

Castells, A., \& Solé-Ollé, A. (2005). The regional allocation of infrastructure investment: The role of equity, efficiency and political factors. European Economic Review, 49(5), 1165-1205). http://dx.doi.org/10.1016/j.euroecorev.2003.07.002.

Doroshenko, Y. A., \& Baidina, O. V. (2008). Russian power depends on regions: Investment ensuring reproductive stability of the region. Retrieved from http://www.creativeconomy.ru/articles/5116/

Expert RA Rating Agency. (2014). Russian Federation, Moscow. Retrieved from http://raexpert.org/ratings/

Folomyev, A., \& Revazo, V. (1999). The investment climate in the regions of Russia and ways of its improvement. Voprosy economiki, 9, 10-15.

Golaydo, I. M. (2008). Investment Potential of the Region. The Regional Economy, 17(74), 59-68.

Golaydo, I. M. (2009). Economic Integration and Investment Opportunities of the Region. The Regional Economy, 7(100), 30-42.

Khachaturov, T. S. (1973). Improvement of methods for determining the effectiveness of capital investments. Voprosy economiki, 3, 82-87.

Kihlgren, A. (2003). Small business in Russia - factors that slowed its development: an analysis. Communist and Post-Communist Studies, 36(2), 193-207. http://dx.doi.org/10.1016/S0967-067X(03)00025-4.

Lavrov, S. B., \& Sdasyuk, G. V. (1984). The evolution of regional development concepts: some new trends. Geoforum, 15(1), 11-17). http://dx.doi.org/10.1016/0016-7185(84)90005-8. 
Miroyedov, A. A., \& Sharamigina, O. A. (2013). The use of gross regional product in assessing the economic development of the region. VoprosyStatistiki, 9, 29-36.

Platon, V., \& Constantinescu, A. (2014). Monte Carlo Method in Risk Analysis for Investment Projects. Procedia Economics and Finance, 15, 393-400. http://dx.doi.org/10.1016/S2212-5671(14)00463-8.

Podshivalenko, G. P., \& Kiselyova, N. V. (2005). Investment business (p. 432). Moscow: Knorus.

Richardson, H. W., \& Townpoe, P. M. (1987). Chapter 16 Regional policies in developing countries, In P. Nijkamp (Ed.), Handbook of Regional and Urban Economics (Chapter 16, Vol. 1, pp. 647-678). Elsevier, http://dx.doi.org/10.1016/S1574-0080(00)80019-X

Rolik, Yu. A. (2013). A Complex Approach to Evaluating the Innovation Strategy of a Company to Determine its Investment Attractiveness. Procedia - Social and Behavioral Sciences, 99, 562-571. http://dx.doi.org/10.1016/j.sbspro.2013.10.526.

Sabirova, M., Fazlyeva, E. \& Feifer-Shishkina, R. (2014). Impact of Monopsonical Labor Market on the Development of Regions of Russian Federation. Procedia Economics and Finance, 15, 363-370. http://dx.doi.org/10.1016/S2212-5671(14)00449-3

Safiullina, A., Fatkhiev, A., \& Ulesov, D. (2014). The Main Categories of Innovative Economy. Procedia Economics and Finance, 15, 459-465. http://dx.doi.org/10.1016/S2212-5671(14)00482-1

Săvoiu, G., \& Țaicu, M. (2014). Foreign Direct Investment Models, based on Country Risk for Some Post-socialist Central and Eastern European Economies. Procedia Economics and Finance, 10, 249-260. http://dx.doi.org/10.1016/S2212-5671(14)00300-1

Shmelev, S. E. (2011). Dynamic sustainability assessment: The case of Russia in the period of transition (1985-2008). Ecological Economics, 70(1), 2039-2049, http://dx.doi.org/10.1016/j.ecolecon.2011.06.003.

Sivelkin, V. A., \& Poltavchenko, G. S. (2002). The investment component of the CFO regions. Foreign trade, 4, 3-5.

Soboleva, Y. P., \& Golaydo, I. M. (2014). Innovative and Investment Activity of the Region. The Orelgiet Bulletin, 3, 18-25.

Soboleva, Y. P., \& Golaydo, I. M. (2014). Social and Economic Development of the Region (as exemplified in the Oryol region). The Scientific Notes of Orelgiet, 1, 118-123.

Valinurova, L. S., \& Kazakova, O. B. (2013). Evaluation of investment attractiveness of the regions of the Volga Federal District: the factors and conditions to attract investment. Retrieved from http://region.mcnip.ru/ modules.php?name $=$ News \&file $=$ print $\&$ sid $=301$

\section{Copyrights}

Copyright for this article is retained by the author(s), with first publication rights granted to the journal.

This is an open-access article distributed under the terms and conditions of the Creative Commons Attribution license (http://creativecommons.org/licenses/by/3.0/). 